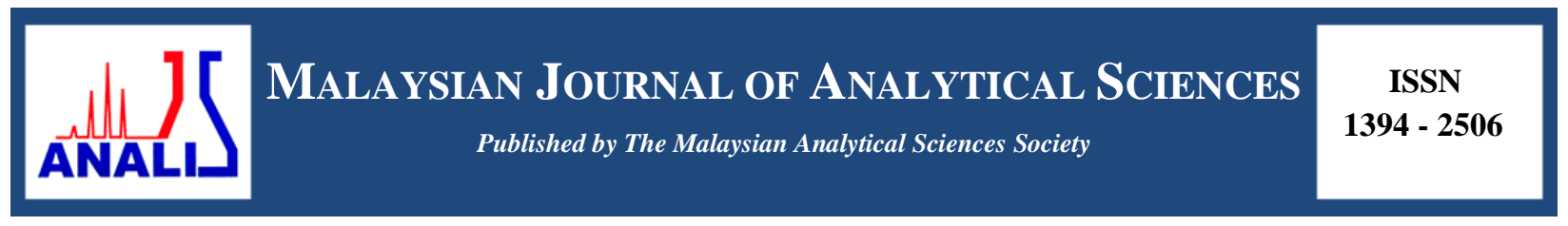

\title{
OXYGEN REDUCTION REACTION BEHAVIOURS OF CARBON NANOTUBES SUPPORTING Pt CATALYST FOR PROTON EXCHANGE MEMBRANE FUEL CELL
}

\author{
(Sifat Tindak Balas Penurunan Oksigen bagi Tiub Nanokarbon Disokong Mangkin Pt bagi \\ Membran Penukaran Proton Sel Bahan Api) \\ Md Ahsanul Haque ${ }^{1,2}$, Abu Bakar Sulong ${ }^{1,3}$, Edy Herianto Majlan ${ }^{1}$, Kee Shyuan Loh $^{1}$, Teuku Husaini ${ }^{1}$, \\ Rosemilia Rosli ${ }^{1}$ \\ ${ }^{1}$ Fuel Cell Institute, \\ Universiti Kebangsaan Malaysia, 43600 UKM Bangi, Selangor, Malaysia \\ ${ }^{2}$ Department of Applied Chemistry and Chemical Engineering, \\ Islamic University, Kushtia-7003, Bangladesh \\ ${ }^{3}$ Department of Mechanical and Materials Engineering, Faculty of Engineering and Built Environment, \\ Universiti Kebangsaan Malaysia, 43600 UKM Bangi, Selangor, Malaysia \\ *Corresponding author: ahsan.chem38@gmail.com
}

Received: 13 April 2017; Accepted: 17 April 2018

\begin{abstract}
Sluggish oxygen reduction reaction (ORR) in cathode electrode is the most common problem in Proton Exchange Membrane (PEM) fuel cell systems. In this study, the ORR behaviours of a half-cell in the cathodic part were investigated which had an impact on its catalyst activity. The electrode was synthesized from multi-walled carbon nanotubes (MWCNT) supported platinum $(\mathrm{Pt})$ catalyst, assigned as $\mathrm{MWCNT} / \mathrm{Pt}$, using an impregnation method. In this case, the hexachloroplatinic acid $\left(\mathrm{H}_{2} \mathrm{PtCl}_{6} \cdot 6 \mathrm{H}_{2} \mathrm{O}\right)$ acts as a Pt metal catalyst precursor. The PTFE (polytetrafloro-ethylene) was also used as sub-supporting material with MWCNT to produce MWCNT/PTFE composite. The Pt is deposited onto the surface of MWCNT/PTFE composite which forms MWCNT/PTFE/Pt electrode. Using CV and RRDE techniques, the electrochemical phenomena of MWCNT/Pt and MWCNT/PTFE/Pt electrodes in the $0.1 \mathrm{M} \mathrm{KOH}$ electrolyte solutions were analysed and compared. The electron transfer (n) from the K-L plot was recorded as 3.89 and 3.77 for $\mathrm{MWCNT} / \mathrm{Pt}$ and $\mathrm{MWCNT} / \mathrm{PTFE} / \mathrm{Pt}$ electrode respectively. Based on the chronoamperometric analysis, the MWCNT/PTFE/Pt was found to be more stable than MWCNT/Pt. Therefore, the MWCNT/PTFE/Pt electrode may be recommended for PEM fuel cell application considering its electrochemical activity.
\end{abstract}

Keywords: oxygen reduction reaction, multi-walled carbon nanotube, cyclic voltammetry, chronoamperometric analysis

\section{Abstrak}

Kelembapan tindak balas penurunan oksigen (ORR) dalam katod elektrod adalah cabaran utama dalam sistem membran penukar proton (PEM) sel bahan api. Dalam kajian ini, tindak balas bagi ORR setengah-sel dikaji pada bahagian katod yang merupakan sebahagian daripada aktiviti pemangkin. Elektrod terhasil disintesis daripada tiub nanocarbon multi dinding (MWCNT) disokong pemangkin platinum (Pt) yang membentuk MWCNT/Pt dengan menggunakan kaedah pengisian. Dalam kes ini, asid heksakloroplatinik $\left(\mathrm{H}_{2} \mathrm{PtCl}_{6} 6 \mathrm{H}_{2} \mathrm{O}\right)$ bertindak sebagai pemangkin logam Pt pelopor. PTFE (politetrafloro-etilena) juga digunakan sebagai bahan sokongan tambahan dengan MWCNT untuk menghasilkan MWCNT/PTFE komposit. Kemudian, Pt telah ditambah ke atas permukaan MWCNT/PTFE komposit yang membawa kepada pembentukan MWCNT/PTFE/Pt elektrod. Berdasarkan kaedah CV dan RRDE telah dianalisis dan dibandingkan fenomena elektrokimia dengan menggunakan kandungan larutan elektrolit 0.1 M KOH bagi setiap bahan MWCNT/Pt dan MWCNT/PTFE/Pt elektrod. Pemindahan elektron (n) dari plot 
K-L juga dikira dan direkodkan sebagai 3.89 bagi MWCNT/Pt dan 3.77 bagi MWCNT/PTFE/Pt elektrod. Berdasarkan analisis kronoamperometrik, MWCNT/PTFE/Pt adalah lebih stabil berbanding MWCNT/Pt. Oleh itu, elektrod MWCNT/PTFE/Pt adalah disyorkan untuk aplikasi PEM sel fuel dengan mengambilkira aktiviti elektrokimia.

Kata kunci: tindak balas penurunan oksigen, karbon nanotiub berbilang, kitaran volmetrik, analisis kronoamperometrik

\section{Introduction}

Green energy technology is fast developing due to the finite nature of fossil fuel reserves. There are also related concerns the $\mathrm{CO}_{2}$ gas emission has boosted the popularity of green energy. Therefore, researchers are focusing on green energy generation especially solar cell and fuel cell technology. Proton exchange membrane fuel cell (PEMFC) is one of the prominent potential energy conversion devices in the fuel cell arena [1]. However, its commercial application has been limited due to a shortage of research on electrode catalysts. Electrode catalyst is the core of PEMFC and plays a vital role in electrochemical reactions. Therefore, the PEMFC's overall performance depends on electro-catalytic activity of cell.

Electrode catalyst is commonly synthesized from precise metals, such as platinum (Pt), and its alloys [nickel (Ni), ruthenium $(\mathrm{Ru})$, rubidium $(\mathrm{Rb})$, palladium $(\mathrm{Pd})]$ are still widely used [2]. The Pt in particular is used for electrode catalyst fabrication. However, it is an expensive metal and therefore to reduce the Pt content in electrocatalyst, carbon supporting materials, such as carbon black, carbon powder, carbon cloth and carbon fiber among others have been used [3]. These are low cost materials with active surface area that enhances electrochemical reactions as well as provide the physical stability for electrodes.

At high operating temperature, the conventional supporting materials may face problems, such as Pt catalyst agglomeration, Pt migration and Pt detachment from the supporting materials [4]. When this happens, it reduces both cell durability and its performance, with respect to time, due to loss of active electrochemical surface area (ECSA) which shows catalyst degradation [5].

In recent years, carbon nanotube, such as single-walled carbon nanotube (SWCNT), multi-walled carbon nanotube (MWCNT) has caught the attention of researchers as catalyst alternative supporting materials due to their unique characteristics, high aspect ratio, high electron conductivity, and enhanced mass transport capability [6, 7]. The MWNT is effective against carbon corrosion when compared with SWCNT or Vulcan XC-72. Therefore, MWCNT shows better performance than the conventional carbon supporting materials [8].

The cathode reaction kinetics primarily represents oxygen reduction reactions (ORR) of PEMFC. The oxygen reduction reaction at cathode sites is more sluggish than the hydrogen oxidation reaction at anode site. Therefore, the excess or overpotential for ORR has been identified as a major problem for the cell performance $[9,10]$ as it consumes more than $80 \%$ of overall cell voltage $[11,12]$. Reducing the over potential of ORR in cathode site is important to increase the PEMFC cell performance [13, 14, 15]. However, degradation is a challenge for PEM fuel cell as it may decrease the lifetime of cell. Catalyst maturation, loss or transfer of catalysts, corrosion of carbon, electrolyte and interface degradation [16], and decrease of the catalyst active surface area due to catalyst agglomeration occur primarily in the cathode [17]. Therefore, this study focuses on the ORR activity as well as the catalyst stability of synthesised MWCNT/Pt and MWCNT/PTFE/Pt electrodes.

\section{Materials and Methods}

Multi walled carbon nanotube (MWCNT), hexachloroplatinic acid $\left(\mathrm{H}_{2} \mathrm{PtCl}_{6} \cdot 6 \mathrm{H}_{2} 0 ; 36 \%\right)$, ortho phosphoric acid $\left(\mathrm{H}_{3} \mathrm{PO}_{4} ; 85 \%\right.$ ), dimethyl acetamide (DMAc; $80 \%$ ), polytetrafloro ethylene (PTFE; 60\%), polybenzimadole (PBI), iso-propyl alcohol (IPA) and potassium hydroxide were purchased from the Sigma-Aldrich. The rotating ring-disk electrode (RRDE) consist of platinum ring and glass carbon (GC) electrode disk and is $5 \mathrm{~mm}$ in diameter, purchased from Pine Instrument Co. All chemicals were in analytical grade. Only deionized (DI) water was used throughout this experiment.

Pristine MWCNT has been oxidized using dual acid mixture of $2.0 \mathrm{M} \mathrm{HNO}_{3} / \mathrm{H}_{2} \mathrm{SO}_{4}$ (v/v 1:3) [18]. The oxidised MWCNT $(5.0 \mathrm{mg})$ and PTFE solution $(50 \mu \mathrm{L})$ was later dissolved in DMAc $(5.0 \mathrm{~mL})$ and sonicated for 60 minutes 
using a bath type sonicator. The mixture was filtered and washed using DMAc to remove excess PTFE. The obtained solid (MWCNT/PTFE) composite was dried in a vacuum drier.

The Pt nanoparticles were later deposited onto the surface of MWCNT/PTFE composite using hexachloro platinic acid $\left(\mathrm{H}_{2} \mathrm{PtCl}_{6} \cdot 6 \mathrm{H}_{2} \mathrm{O}\right)$ and aqueous ethylene glycol solvent. The MWCNT/PTFE mixture $(10 \mathrm{mg})$ was then sonicated and the $\mathrm{H}_{2} \mathrm{PtCl}_{6} \cdot 6 \mathrm{H}_{2} \mathrm{O}(1.4 \mathrm{mM})$ was added to the MWCNT/PTFE mixture solution and continuously stirred for 4 hours at ambient temperature. The followed mixture solution was refluxed at $140{ }^{\circ} \mathrm{C}$ temperature for 8 hours. After refluxing, the solid materials were accumulated by filtration solvent and the unwanted residue washed out using the DI water and dried in vacuum drier to obtain MWCNT/PTFE/Pt [19, 20].

Oxidised MWCNT (10 mg) was later dissolved in aqueous ethylene glycol adding $\mathrm{H}_{2} \mathrm{PtCl}_{6} \cdot 6 \mathrm{H}_{2} \mathrm{O}(1.4 \mathrm{mM})$ for Pt precursor. This solution was stirred for 4 hours under room temperature and again refluxed under $140{ }^{\circ} \mathrm{C}$ temperature for 8 hours, before it was filtered and washed with DI water to remove any unwanted residue. Finally, the solid MWCNT/Pt was dried overnight in a vacuum drier. The synthesised MWCNT/Pt was later characterised and compared with MWCNT/PTFE/Pt.

The MWCNT/PTFE/Pt electrocatalyst films were prepared for electrochemical characterisation. The catalyst was later dissolved in IPA (80\%) solvent and dispersed using ultrasound to attain a homogeneous solution. In this case, the MWCNT/PTFE/Pt catalyst loaded was $0.5 \mathrm{mg} / \mathrm{mL}$ and later $10 \mu \mathrm{L}$ of catalyst solution was dropped onto the polished GC disk of an RRDE using micropipette. The electrode was dried in ambient conditions overnight. Again, $5 \mu \mathrm{L}$ of Nafion (5 wt.\%) ionomer was applied onto the MWCNT/PTFE/Pt electrode film and dried at room temperature. The same procedure was used to develop catalyst film of MWCNT/Pt.

An electrochemical analysis was carried out using Autolab potentiostat/galvanostat (AUT128N) in a three-electrode system under ambient temperature, whereas; glassy carbon, $\mathrm{Ag} / \mathrm{AgCl}$ electrode and $\mathrm{Pt}$ wire were used as working electrode, reference electrode, and counter electrode respectively. The electro-catalytic activities of synthesised MWCNT/PTFE/Pt and MWCNT/Pt electrode toward the oxygen reduction reaction in a $0.1 \mathrm{M} \mathrm{KOH}$ electrolyte solution were analysed using CV and RRDE voltammetry in a negative potential range $0.0 \mathrm{~V}$ to $-1.0 \mathrm{~V}$ with a scan rate of $10 \mathrm{mVs}^{-1}$. Prior to each experiment, the $\mathrm{N}_{2}$ and $\mathrm{O}_{2}$ gas was purged in the $0.1 \mathrm{M} \mathrm{KOH}$ electrolyte solution until saturation. From the third cycle, CV signal was recorded to be stable after few consecutive cycles. The linear sweep voltammetry (LSV) was also accomplished in an $\mathrm{O}_{2}$ gas saturated medium of $0.1 \mathrm{M} \mathrm{KOH}$ electrolyte solution with various rotational speeds in the negative potential range $0.0 \mathrm{~V}$ to $-1.0 \mathrm{~V}$ using the scan rate $10 \mathrm{mVs}^{-1}$. In this paper, all potentials are referred to as $\mathrm{Ag} / \mathrm{AgCl}[21,22]$.

\section{Results and Discussion}

The synthesised electrocatalyst MWCNT/PTFE/Pt and MWCNT/Pt were examined in oxygen and nitrogen gas saturated $0.1 \mathrm{M} \mathrm{KOH}$ electrolyte solution under the three-electrode system. The cyclic voltammetry (CV) curves of MWCNT/PTFE/Pt and MWCNT/Pt were performed at ambient temperature. From Figure 1, very little peak current was observed in case of nitrogen gas saturated of $0.1 \mathrm{M} \mathrm{KOH}$ electrolyte solution used for both synthesised electrodes that indicated almost inactive redox species with respect to $\mathrm{Ag} / \mathrm{AgCl}$ electrode potential within the potential range at $0.0 \mathrm{~V}$ to $-1.0 \mathrm{~V}$. The cathodic peak current was exposed whenever oxygen gas saturated environment of $0.1 \mathrm{M} \mathrm{KOH}$ electrolyte was used. These observations suggest that MWCNT/PTFE/Pt and MWCNT/Pt electrodes successfully induced the ORR reactions in the alkaline media. Figure 1(a) and 1(b) showed that the highest peak current at $-0.38 \mathrm{~V}$ and $-0.22 \mathrm{~V}$ potentials for the MWCNT/Pt and MWCNT/PTFE/Pt electrodes, respectively. The oxygen reduction currents were recorded as $0.28 \mathrm{~mA} \mathrm{~cm}{ }^{-2}$ and $0.22 \mathrm{~mA} \mathrm{~cm}{ }^{-2}$ for the MWCNT/Pt and MWCNT/PTFE/Pt electrodes, respectively.

The RRDE (ring rotating disk electrode) was used to analyse the kinetics of oxygen reduction reaction of MWCNT/Pt and MWCNT/PTFE/Pt electrodes. The LSV (linear sweep voltammogram) curves were obtained based on the electrocatalyst loaded of RRDE using various rotation rates, $200 \mathrm{rpm}, 400 \mathrm{rpm}, 800 \mathrm{rpm}, 1200 \mathrm{rpm}$ and 1600 rpm respectively. The oxygen reduction current was increased corresponding with high rotation rate. KoutechyLevich (K-L) equation suggests sluggish ORR, if reduction current density is constant [23]. From Figure 2, the diffusion limited current density increases corresponding with rotation rate which implies that the ORR is diffusion- 
controlled reaction. The ORR polarization curve exhibited limiting current plateau corresponding with the diffusionlimited current density [21].
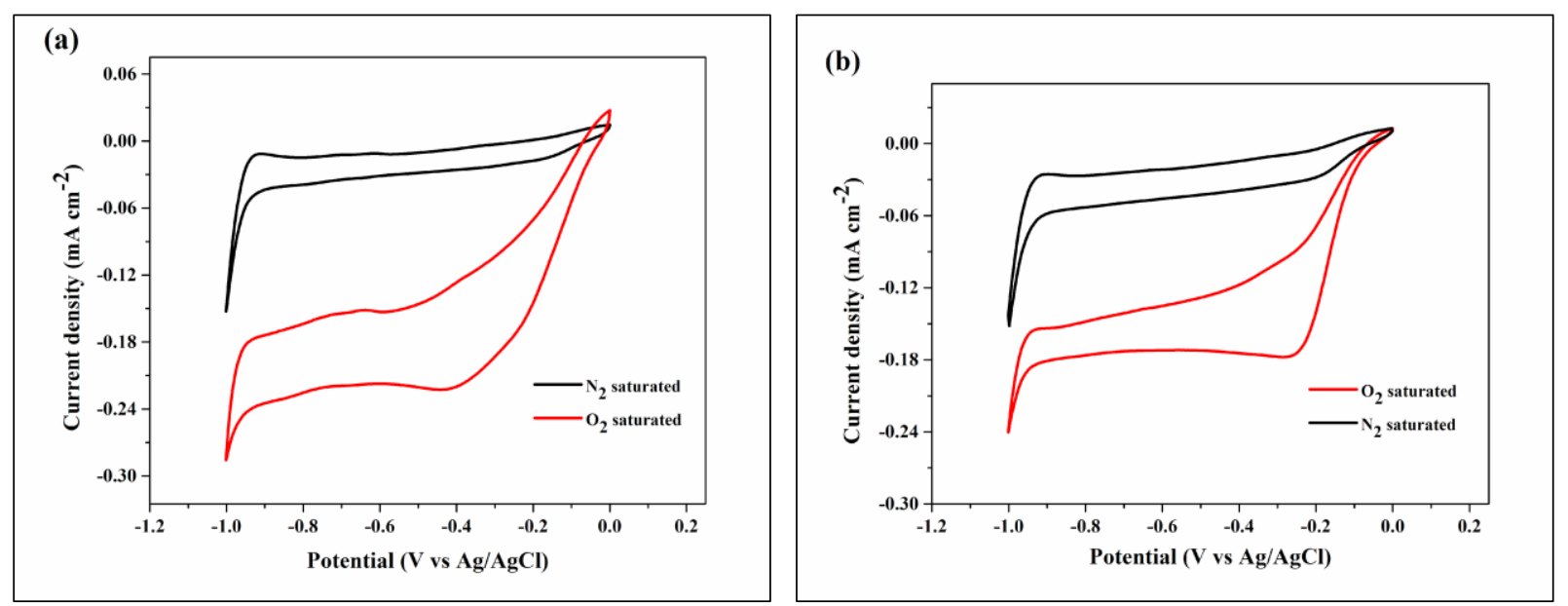

Figure 1. Cyclic voltammogram of (a) MWCNT/Pt and (b) MWCNT/PTFE/Pt electrodes in the $\mathrm{O}_{2}$ and $\mathrm{N}_{2}$ gas saturated of $0.1 \mathrm{M} \mathrm{KOH}$ electrolyte solution (scan rate: $10 \mathrm{mVs}^{-1}$ )

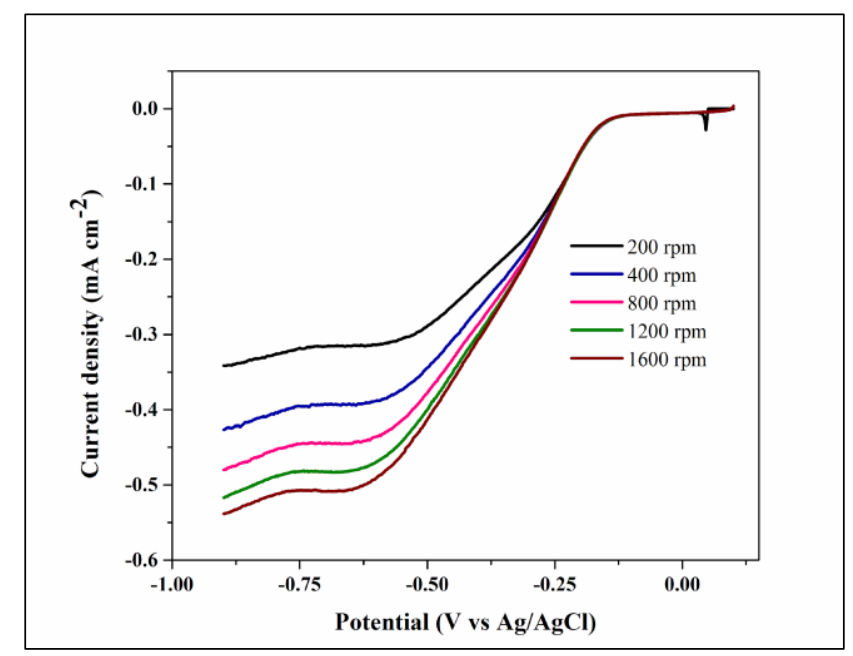

Figure 2. The ORR polarisation curves of MWCNT/PTFE/Pt electrodes in oxygen saturated environment of $0.1 \mathrm{M}$ $\mathrm{KOH}$ electrolyte with different rotation rate (scan rate: $10 \mathrm{mV} \mathrm{s}^{-1}$ )

Generally, the ORR reaction may proceed using either two or four electrons transfer mechanism according to the following equation 1 and 2.

$$
\begin{aligned}
& \mathrm{O}_{2}+2 \mathrm{H}_{2} \mathrm{O}+4 \overline{\mathrm{e}} \rightarrow 4 \mathrm{OH}^{-} \\
& \mathrm{O}_{2}+\mathrm{H}_{2} \mathrm{O}+2 \overline{\mathrm{e}} \rightarrow \mathrm{HO}_{2}{ }^{-}+\mathrm{OH}-
\end{aligned}
$$

However, the peroxide $\left(\mathrm{HO}_{2}-\right)$ species is generated using first reduction process (equation 2) which may yield hydroxide ion (equation 3) [24]; or using a disproportionation reaction to generate hydroxide ions and oxygen gas (equation 4) [25]. 


$$
\begin{aligned}
& \mathrm{HO}_{2}{ }^{-}+\mathrm{H}_{2} \mathrm{O}+2 \overline{\mathrm{e}} \rightarrow 3 \mathrm{OH}^{-} \\
& \mathrm{HO}_{2}{ }^{-} \rightarrow \frac{1}{2} \mathrm{O}_{2}+\mathrm{OH}^{-}
\end{aligned}
$$

Therefore, the overall catalytic activity depends on the ORR mechanism namely total number of electron transfer (n). The K-L plot was drawn according to following equation 5 which provides the value of $n$.

$$
1 / \mathrm{i}=1 / \mathrm{i}_{\mathrm{k}}+1 / \mathrm{i}_{\mathrm{d}}
$$

Whereas, $i, i_{k}$ and $i_{d}$ represent current density, kinetic current density, and diffusion limited current density respectively. The $i_{d}$ can be determined using the Levich equation (equation 6 ) as follows:

$$
\mathrm{i}_{\mathrm{d}}=0.62 \mathrm{nFCC}_{\mathrm{O} 2} \mathrm{D}_{\mathrm{O} 2}^{2 / 3} \mathrm{v}^{-1 / 6} \mathrm{w}^{1 / 2}
$$

where, $\mathrm{n}, \mathrm{F}, \mathrm{C}_{\mathrm{O} 2}, \mathrm{D}_{\mathrm{O} 2}{ }^{2 / 3}, \mathrm{v}^{-1 / 6}$ and $\mathrm{w}^{1 / 2}$ represent the number of electrons consumed by $\mathrm{O}_{2}$ molecule, Faraday constant (96485 $\left.\mathrm{C} \mathrm{mol}^{-1}\right)$, electrolyte oxygen conc. $\left(1.2 \times 10^{-6} \mathrm{~mol} \mathrm{~cm}^{-3}\right)$, oxygen diffusion coefficient $\left(1.9 \times 10^{-5} \mathrm{~cm}^{2} \mathrm{~s}^{-1}\right)$, viscosity of $0.1 \mathrm{M} \mathrm{KOH}$ electrolyte solution $\left(0.01 \mathrm{~cm}^{2} \mathrm{~s}^{-1}\right)$ and rotation speed $\left(\mathrm{rad} \mathrm{s}^{-1}\right)$ respectively [21].

Figure 3 shows two straight lines which represent the K-L plot of MWCNT/Pt and MWCNT/PTFE/Pt electrodes. This linear relationship indicates the $1^{\text {st }}$ order reaction with respect to oxygen molecule. However, the values of $\mathrm{n}$ (total no. of electrons) are 3.89 and 3.77 for the MWCNT/Pt and MWCNT/PTFE/Pt respectively, calculated from the slop of K-L plot. Therefore, the four electron transfer mechanism was involved in the ORR reaction at the negative potential window. From Figure 4(a), it is clear the values of n, approximately 4 at the potential range -0.9 to $-0.2 \mathrm{~V}$. When the potential exceeds -0.2 , then $\mathrm{n}$ abruptly decreases and gradually reaches zero under $0.0 \mathrm{~V}$. It is significant that no appreciable ORR reaction takes place at zero potential. Figure 4(b), on the other hand shows that the yield $\%$ of $\mathrm{HO}_{2}{ }^{-}$species is almost at constant value within the same potential range, namely -0.9 to $-0.2 \mathrm{~V}$.

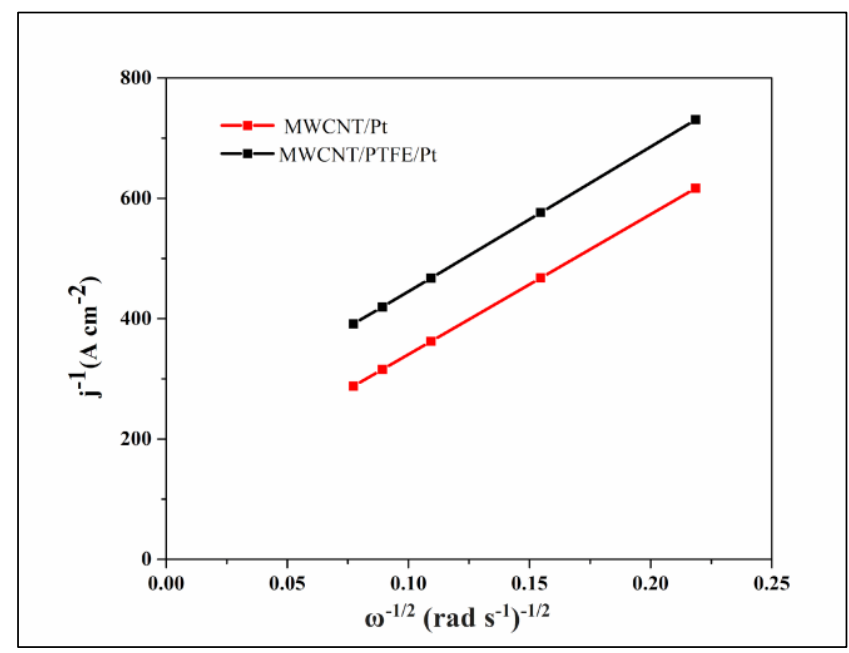

Figure 3. Koutecky-Levich (K-L) plots for MWCNT/Pt and MWCNT/PTFE/Pt electrodes

The performance of electrode stability was examined using the chronoamperometric (CA) analysis. Figure 5 shows the CA curves of the MWCNT/Pt and MWCNT/PTFE/Pt electrode at $0.3 \mathrm{~V}$ for $7200 \mathrm{sec}$ in $0.1 \mathrm{KOH}$ electrolyte solution. The retention rate refers to the stability of electrode catalyst and is calculated by the ratio of final current density to the initial current density from the chronoamperometric curves [26]. The final current densities of MWCNT/Pt and MWCNT/PTFE/Pt are 0.0063 and $0.0075 \mathrm{~mA} / \mathrm{cm}^{2}$ and their initial current densities are 0.02987 and $0.01452 \mathrm{~mA} / \mathrm{cm}^{2}$, respectively. In addition, the retention rates are 0.211 and 0.517 for the MWCNT/Pt and MWCNT/PTFE/Pt catalyst respectively.These results therefore indicate MWCNT/PTFE/Pt electrode is more stable 
owing to its high retention rate compared with the MWCNT/Pt, although it produced slightly less current densities. The PTFE acts as binder between the Pt catalyst and MWCNT supporting materials. This may be helpful for future research on catalyst stability.
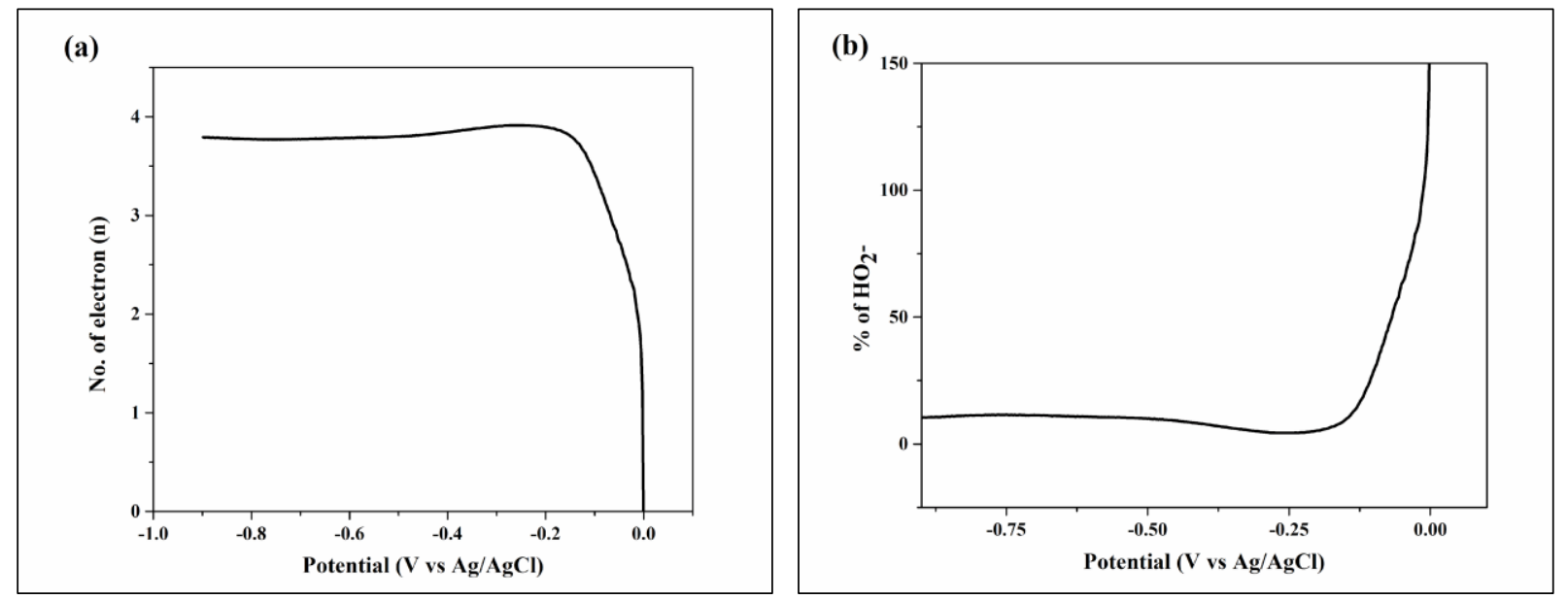

Figure 4. (a) Plot of electrons transfer number (n) $v s$ potential and (b) $\% \mathrm{of}_{\mathrm{HO}_{2}}{ }^{-}$vs potential for $\mathrm{MWCNT} / \mathrm{PTFE} / \mathrm{Pt}$ electrode.

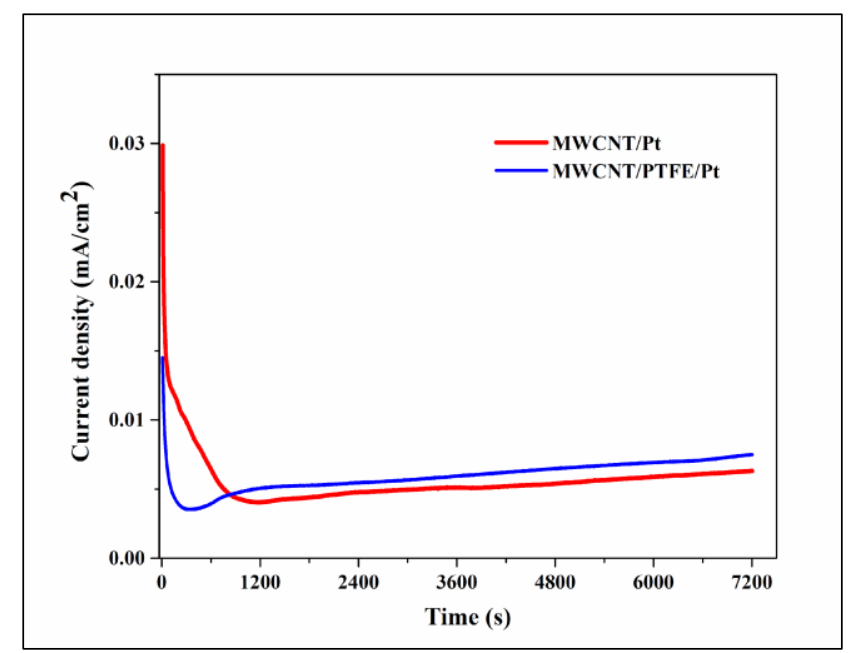

Figure 5. The chronoamperometric curves for synthesised catalyst in $0.1 \mathrm{KOH}$ electrolyte solution at $0.3 \mathrm{~V}$

\section{Conclusion}

This study synthesised the MWCNT/PTFE/Pt and MWCNT/Pt electrocatalyst and showed promising electrocatalytic activity. It examined electrochemical phenomena at negative potential window $(-0.9 \mathrm{~V}$ to $0.0 \mathrm{~V})$. The oxygen reduction peak currents were recorded as $0.28 \mathrm{~mA} \mathrm{~cm}^{-2}$ and $0.22 \mathrm{~mA} \mathrm{~cm}$ at the potential $-0.38 \mathrm{~V}$ and $0.22 \mathrm{~V}$ respectively for MWCNT/Pt and MWCNT/PTFE/Pt electrode. Four electron transfer mechanism were involved in the ORR reaction. Based on the K-L plot, the values of $n$ are calculated as 3.89 and 3.77 for MWCNT/Pt and MWCNT/PTFE/Pt electrode, respectively. Moreover, the ratios of current densities have recorded as 0.517 and 0.211 for MWCNT/PTFE/Pt and MWCNT/Pt electrode respectively. 


\section{Acknowledgement}

The authors are indebted to Universiti Kebangsaan Malaysia for providing financial support to undertake this study under Grant AP-2013-010 and TRGS/2/3014/UKM/02/4/1.

\section{References}

1. Haque, M. A., Sulong, A. B., Loh, K. S., Majlan, E. H., Husaini, T. and Rosli, R. E. (2017). Acid doped polybenzimidazoles based membrane electrode assembly for high temperature proton exchange membrane fuel cell: A review. International Journal of Hydrogen Energy, 42(14): 9156-9179.

2. Paulus, U. A., Wokaun, A., Scherer, G. G., Schmidt, T. J., Stamenkovic, V., Radmilovic, V., Markovic, M. and Ross, P. N. (2002). Oxygen reduction on carbon-supported $\mathrm{Pt}-\mathrm{Ni}$ and $\mathrm{Pt}-\mathrm{Co}$ alloy catalysts. The Journal of Physical Chemistry B, 106(16): 4181-4191.

3. Kangasniemi, K. H., Condit, D. A. and Jarvi, T. D. (2004). Characterization of vulcan electrochemically oxidized under simulated PEM fuel cell conditions. Journal of The Electrochemical Society, 151(4): E125E132.

4. Inaba, M. (2009). Durability of electrocatalysts in polymer electrolyte fuel cells. ECS Transactions, 25(1): 573581.

5. Li, Q., Aili, D., Hjuler, H. A. and Jensen, J. O. (2016). High temperature polymer electrolyte membrane fuel cells. Springer, Switzerland.

6. Li, W., Liang, C., Qiu, J., Zhou, W., Han, H., Wei, Z., Gongquan, S. and Xin, Q. (2002). Carbon nanotubes as support for cathode catalyst of a direct methanol fuel cell. Carbon, 40(5): 787-790.

7. Wang, C., Waje, M., Wang, X., Tang, J. M., Haddon, R. C. and Yan, Y. (2004). Proton exchange membrane fuel cells with carbon nanotube based electrodes. Nano Letters, 4(2): 345-348.

8. Wang, X., Li, W., Chen, Z., Waje, M. and Yan, Y. (2006). Durability investigation of carbon nanotube as catalyst support for proton exchange membrane fuel cell. Journal of Power Sources, 158(1): 154-159.

9. Kinoshita, K. (1992). Electrochemical oxygen technology. John Wiley \& Sons.

10. Kordesch, K. and Simader, G. (1996). Fuel cells and their applications. Weinheim: VCh.

11. Bernardi, D. M. and Verbrugge, M. W. (1992). A mathematical model of the solid- polymer- electrolyte fuel cell. Journal of the Electrochemical Society, 139(9): 2477-2491.

12. Toda, T., Igarashi, H., Uchida, H. and Watanabe, M. (1999). Enhancement of the electroreduction of oxygen on Pt alloys with Fe, Ni, and Co. Journal of the Electrochemical Society, 146(10): 3750-3756.

13. Hiesgen, R., Eberhardt, D., Aleksandrova, E. and Friedrich, K. A. (2006). Structure and local reactivity of supported catalyst/Nafion ${ }^{\circledR}$ layers studied by in- situ STM. Fuel Cells, 6(6): 425-431.

14. Ralph, T. R. and Hogarth, M. P. (2002). Catalysis for low temperature fuel cells. Platinum Metals Review, 46(3): 117-135.

15. Yu, X., \& Ye, S. (2007). Recent advances in activity and durability enhancement of Pt/C catalytic cathode in PEMFC: Part I. Physico-chemical and electronic interaction between Pt and carbon support, and activity enhancement of Pt/C catalyst. Journal of Power Sources, 172(1): 133-144.

16. Zhang, S., Yuan, X. Z., Hin, J. N. C., Wang, H., Friedrich, K. A. and Schulze, M. (2009). A review of platinum-based catalyst layer degradation in proton exchange membrane fuel cells. Journal of Power Sources, 194(2): 588-600.

17. Silva, R. A., Hashimoto, T., Thompson, G. E. and Rangel, C. M. (2012). Characterization of MEA degradation for an open air cathode PEM fuel cell. International Journal of Hydrogen Energy, 37(8): 7299-7308.

18. Scheibe, B., Borowiak-Palen, E. and Kalenczuk, R. J. (2010). Oxidation and reduction of multiwalled carbon nanotubes - preparation and characterization. Materials Characterization, 61(2): 185-191.

19. Berber, M. R., Hafez, I. H., Fujigaya, T. and Nakashima, N. (2015). A highly durable fuel cell electrocatalyst based on double-polymer-coated carbon nanotubes. Scientific Reports, 5: 16711.

20. Okamoto, M., Fujigaya, T. and Nakashima, N. (2009). Design of an assembly of poly (benzimidazole), carbon nanotubes, and pt nanoparticles for a fuel- cell electrocatalyst with an ideal interfacial nanostructure. Small, 5(6): 735-740.

21. Toh, S. Y., Loh, K. S., Kamarudin, S. K. and Daud, W. R. W. (2016). The impact of electrochemical reduction potentials on the electrocatalytic activity of graphene oxide toward the oxygen reduction reaction in an alkaline medium. Electrochimica Acta, 199: 194-203. 
22. Soo, L. T., Loh, K. S., Mohamad, A. B., Daud, W. R. W. and Wong, W. Y. (2016). Effect of nitrogen precursors on the electrochemical performance of nitrogen-doped reduced graphene oxide towards oxygen reduction reaction. Journal of Alloys and Compounds, 677: 112-120.

23. Wong, W. Y., Daud, W. R. W., Mohamad, A. B., Kadhum, A. A. H., Loh, K. S. and Majlan, E. H. (2013). Recent progress in nitrogen-doped carbon and its composites as electrocatalysts for fuel cell applications. International Journal of Hydrogen Energy, 38(22): 9370-9386.

24. Allen, J. B., Parsons, R. and Jordan, J. (1985). Standard potentials in aqueous solution. Monographs in Electroanalytical Chemistry and Electrochemistry, Dekker Marcel, Inc., New York-Basel.

25. Maldonado, S. and Stevenson, K. J. (2005). Influence of nitrogen doping on oxygen reduction electrocatalysis at carbon nanofiber electrodes. The Journal of Physical Chemistry B, 109(10): 4707-4716.

26. Abdullah, M., Kamarudin, S. K. and Shyuan, L. K. (2016). $\mathrm{TiO}_{2}$ nanotube-carbon (TNT-C) as support for Ptbased catalyst for high methanol oxidation reaction in direct methanol fuel cell. Nanoscale Research Letters, 11(1): 553. 